\title{
The Taking of Evidence in a Fair Trial in the Light of the ECtHR - Especially the Protection of Confidential Information or State Secrets as Evidence
}

This article deals with the requirements of a fair trial while taking evidence in court. In particular, it outlines the content and scope of rights when examining defence or prosecution witnesses, and procuring documentary or other material evidence. Furthermore, it explores the extent to which confidential information or state secrets may be protected during the taking of evidence in court, and the limits placed on the application of such protective measures by the defence's right to a fair trial.

\section{Introduction}

The imperative of an effective fight against serious crime, i.e., terrorism, organised crime, economic crime, etc., led to, not only to the introduction of several secret and undercover investigative methods by the police, but also to the increasing influence of intelligence services and other non-judicial bodies on criminal justice. ${ }^{1}$ One of the most striking consequences of these developments for the criminal justice system is the persistent interest of crime investigation and intelligence authorities in protecting the

* Dr. LL.M (Freiburg), University of Eskișehir Osmangazi.

1 B. Vogel, 'In camera' - Verfahren als Gewährung effektiven Rechtsschutzes? Neue Entwicklungen im europäischen Sicherheitsrecht, Zeitschrift für Internationale Strafrechtsdogmatik, (ZIS) 1/2017, p. 28 et seq.; E. Nanopoulos, European Human Rights Law and the Normalisation of the 'Closed Material Procedure': Limit or Source? Modern Law Review (MLR) 78(6)/ 2015, p. 913 et seq.; for corresponding legislative activities at the level of the Council of Europe see Parliamentary Assembly Resolution 2038 (2015) on witness protection as an indispensable tool in the fight against organised crime and terrorism in Europe [http://assembly.coe.int/ nw/xml/XRef/Xref-XML2HTML-en.asp?fileid=21551\&lang=en]; Parliamentary Assembly Resolution 1838 (2011), Abuse of state secrecy and national security: obstacles to parliamentary and judicial scrutiny of human rights violations [http://assembly.coe.int/nw/xml/XRef/X ref-XML2HTML-EN.asp?fileid=18033\&lang=en]; Recommendation Rec(2005)9 of the Council of Europe Committee of Ministers to member states on the protection of witnesses and collaborators of justice [https://www.coe.int/t/dg1/legalcooperation/economiccrime/orga nisedcrime/Rec\%20_2005_9.pdf]; Recommendation Rec(2001) 11 of the Committee of Ministers to member states concerning the guiding principles of the fight against organised crime [https://rm.coe.int/1680092b86]. 
confidentiality of their methods and knowledge (mostly described as confidential information, ${ }^{2}$ confidential material ${ }^{3}$ or state secrets ${ }^{4}$ ) during the course of criminal proceedings, including the taking of evidence by the trial court. This approach causes substantial problems to longstanding procedural principles and defence rights in many countries. ${ }^{5}$ Moreover, the European Court of Human Rights (ECtHR) is increasingly dealing with such cases. ${ }^{6}$ This is particularly true for the taking of evidence in the trial court, which is the subject matter of this contribution. ${ }^{7}$

The main yardstick that the Court applies in the case of complaints regarding confidentiality and secrecy measures in criminal trials is the right to a fair trial according to Article 6 (1) European Convention on Human Rights (ECHR) in the shape of some specific defence principles and rights, which the Court reads into the concept of fairness. Therefore, in order to determine the scope of the protection of state secrets as evidence, respectively, the remedies of Article 6 (1) ECHR for the defence in such cases, one needs to outline the underlying assumptions of the concept of 'fairness' with regard to the principles of evidence-taking by the court, or the right of defence to request the taking of evidence. In this regard, it is worthwhile carving out how the right of defence to request evidence operates, in particular, to create groups of cases that have found their way into the case-law of the ECtHR (II.). This analysis will illustrate the extent to which some secrecy considerations are allowed in a fair trial according to Article 6 (1) ECHR, and what constitutes the limits of the protection of confidential information or state secrets as evidence in criminal trials.

Before discussing the above-described proposal, I would like to highlight the main structures based on Article 6 (1) ECHR with regard to the subject matter of this contribution. Under this provision, a defendant has, first of all, two primary remedies: the right to call a defence witness and examine a prosecution witness in accordance with Article 6 (3) lit. d ECHR (III.), and the right to request documentary or other material evidence as a specification of the principles of equality of arms and adversarial hearing

2 ECtHR, Murray v. The United Kingdom, Application no. 14310/88, Judgement 28 October 1994, margin no 58.

$3 E C t H R, A$. and others v. The United Kingdom, Application no. 3455/05, Judgement 19 February 2009, margin no 210.

4 See, for instance, ECtHR, Scholer v. Germany, Application no. 14212/10, Judgement 18 December 2014, margin no 31 et seq.

5 For a comprehensive study on the countries of the United Kingdom, France, Germany, Italy, Spain, the Netherlands and Sweden see the European Parliament Policy Department. National security and secret evidence in legislation and before the courts: exploring the challenges [https://www.google.de/search?q=european+parliament+policy+department+national+securi ty+and+secret+evidence\&rlz=1C1GCEB_enDE793DE793\&oq=european+parliament+policy +department+national+security+and+secret+evidence+\&aqs=chrome..69i57.23158j1j7\&sourc eid=chrome\&ie $=U T F-8]$.

6 In this regard see also F. Fabbrini, The European Court of Human Rights, Extraordinary Renditions and the Right to the Truth: Ensuring Accountability for Gross Human Rights Violations Committed in the Fight Against Terrorism, Human Rights Law Review (HRLRev) 2013, p. 1 et seq.

7 For the use of secret evidence with regard to other restrictive measures see Vogel, ZIS 1/2017, p. 29 et seq.; Nanopoulos, MLR 78(6)/2015, p. 918 et seq. 
(IV.). Secondly, the transparency of the criminal proceedings is guaranteed by the right of the defence to access the case files, and to a public court hearing and court judgment (V.).

\section{General concept}

From the right to a 'fair... hearing' within the meaning of Article 6 (1) ECHR, the Court derives, besides the requirement of an oral hearing, other principles and defence rights. The fairness of a hearing is achieved for the Court by affording a certain equality of arm between the prosecution and defence. This principle requires 'that each party be afforded a reasonable opportunity to present his case under conditions that do not place him at a disadvantage vis-à-vis his opponent'. ${ }^{8}$ Bearing in mind that the prosecution authority will be closely affiliated with the judiciary and will rely on considerable state power, this principle aims to counter the existing disparity between the prosecution and the defence. ${ }^{9}$ In addition to the rather general imperative of equality of arms, the fairness concept of Article 6 (1) ECHR specifically requires that the prosecution discloses all the material in his possession for and against the defendant. ${ }^{10}$ The duty of disclosure specifically enables the defence to file a motion with regard to evidence, which is at the disposal of the prosecution.

By affording the principle of equality of arms and duty of disclosure, Article 6 (1) implicitly enshrines the fundamental right of the defendant that criminal proceedings should be adversarial. This means, in broad terms, 'in a criminal case that both prosecution and defence must be given the opportunity to have knowledge of and comment on the observations filed and the evidence adduced by the other party'. ${ }^{11}$ More specifically, the principle of adversarial hearing requires, inter alia, that the defendant has the right to be present, to follow proceedings and to have his case 'heard'. ${ }^{12}$ The Court further specifies the right to be heard by the requirement that the defendant has the opportunity 'to give evidence in his own defence, hear the evidence against him, and examine' it. $^{13}$

8 ECtHR, Moiseyev v. Russia, Application no. 62936/00, Judgement 9 October 2008, margin no 203.

9 See also European Commission on Human Rights (ECionHR), Jespers v. Belgium, Application no. 8403/78, Report 14 December 1981, margin no 70.

10 ECtHR, Dowsett v. The United Kingdom, Application no. 39482/98, Judgement 24 June 2003, margin no 41; see also Nanopoulos, MLR 78(6)/2015, p. 922; K. Gaede, Schranken des fairen Verfahrens gemäß Art. 6 EMRK bei der Sperrung verteidigungsrelevanter Informationen und Zeugen, Strafverteidiger (StV) 2006, p. 600.

11 ECtHR, Öcalan v. Turkey, Application no. 46221/99, Judgement 12 May 2005, margin no 146; ECtHR, Dowsett v. The United Kingdom, (fn. 10), margin no 41.

12 ECtHR, Ziliberberg v. Moldova, Application no. 61821/00, Judgement 1 February 2005, margin no 40.

13 ECtHR, Jussila v. Finland, Application no. 73053/01, Judgement 23 November 2006, margin no 40; J. Renzikowski, Fair trial und anonymer Zeuge. Die Drei-Stufen-Theorie des Zeugenschutzes im Lichte der Rechtsprechung des EuGHMR, Juristenzeitung (JZ) 12/1999, p. 609. 
The above-outlined principles of a fair hearing and defence rights display, even if still remaining quite general, a certain backbone to Article 6 (1) ECHR, insofar as the determination of a criminal charge by the trial court and the concerning evidence. Moreover, the close relationship between the general notion of fairness in Article 6 (1) and the 'minimum rights' of the defendant in Article 6 (3) must be taken into consideration. The latter provision specifies in one way or another the requirements of the former: in particular, the right to have 'adequate ... facilities for the preparation of his defence' in accordance with Article 6 (3) lit. b, which reflects the very idea for strengthening the position of the defence in criminal proceedings. ${ }^{14}$ By non-compliance with the duty of disclosure, the prosecution will also violate Article 6 (3) lit. b ECHR. ${ }^{15}$ The principle of the equality of arms in an adversarial hearing and the right to be heard are, in fact, best reflected by Article 6 (3) lit. $\mathrm{d}$, which contains the right of the defendant 'to examine or have examined witnesses against him and to obtain the attendance and examination of witnesses on his behalf under the same conditions as witnesses against him'. ${ }^{16}$

As the above summary shows, the principles and defence rights of Article 6 ECHR are closely affiliated with one other. ${ }^{17}$ To date, however, the Court avoids determining the scope and boundaries of single rights and strictly safeguards the flexibility of its content, rather than the 'broad picture', namely, the fairness of the whole criminal trial. Thus, the above undertaken determinations only fragmentarily represent the right to a fair trial within the meaning of Article 6 ECHR. ${ }^{18}$ Despite this conceptualisation problem of Article 6, one should not overlook the comprehensive case-law of the Court which shows, even if case-based, how the requirements of fairness unfolds its protection with regard to specific issues of evidence-taking by the trial court. A closer look into the case-law of the Court reveals shortcomings in the principle of fairness with regard to, at least, the following evidence requests of the defendant:

14 The right to be informed about the accusations against him, in accordance with Article 6 (3) lit. a ECHR, must be interpreted in relation to Article 6 (3) lit. b ECHR, in the sense that the informing person should put the defendant in a position to adequately prepare his defence; see also the ECionHR, R.L v. The Netherlands, Application no. 22520/93, Decision 18 May 1995, margin no Law.

15 ECtHR, Leas v. Estonia, Application no. 59577/08, Judgement 6 March 2012, margin no 81.

16 See also J. Pauly, Konfrontationsrecht der Verteidigung bei Zeugenaussagen. Anmerkung zu EGMR H./. Deutschland Urt. v. 19.07.2012, Strafverteidiger (StV) 2014, p. 456; K.F. Stoffers, Anwesenheitsrechte des Verteidigers bei Zeugenvernehmung im Ermittlungsverfahren, Neue Juristische Wochenschrift (NJW) 2013, p. 1496.

17 ECtHR, Karelin v. Russia, Application no. 926/08, Judgement 20 September 2016, margin no 59 .

18 See also Gaede, StV 2006, p. 601. 
- to change the way of the taking of evidence with regard to certain types of evidence, which are, for instance, at the disposal of the prosecution ${ }^{19}$ or another authority, ${ }^{20}$

- to procure certain types of evidence that are at the disposal of the prosecution ${ }^{21}$ or another authority, 22

- to adduce a documentary evidence which the defendant himself has at his disposal, ${ }^{23}$

- to adduce a defence witness whom he names ${ }^{24}$ or could not name, ${ }^{25}$ and

- to examine a prosecution witness whose testimonies have already been introduced into trial. ${ }^{26}$

Also in relation to the evidence requests made by the defence, the Court emphasises that the judge is 'the ultimate guardian of the fairness of the proceedings' ${ }^{27} \mathrm{He}$ is not only obliged to afford a certain equality of arms between the prosecution and defence, an adversarial trial, and guarantee the rights of defence, but also to ensure that the conviction of the defendant suffers no miscarriage of justice, notably, any wrongfulness due to shortcomings in the taking of evidence..$^{28}$

The specific principle or right on which the Court or applicants base their conclusions or claims seems to be divided, broadly speaking, into two areas: insofar as the evidence request concerns a prosecution or defence witness including an expert witness, Article 6 (3) lit. d ECHR finds as a specific aspect of fairness the direct application. If the evidence in question is a document or other material evidence, the duty of disclosure or the general right of the defence to request evidence is applicable. Al-

19 ECionHR, Jespers v. Belgium, (fn. 9), margin no 60 et seq.; ECionHR, C.G.P v. The Netherlands, Application no. 29835/96, Decision 15 January 1997, margin no 1.

20 ECtHR, Georgios Papageorgiou v. Greece, Application no. 59506/00, Judgement 9 May 2003, margin no 35 et seq.

21 ECionHR, Näss v. Sweden, Application no. 18066/91, Decision 6 April 1994, margin no lb Law.

22 ECtHR, Mirea v. Romania, Application no. 19314/07, Judgement 6 October 2015, margin no 41; ECtHR, Bucur und Toma v. Romania, Application no. 40238/02, Judgement 8 January 2013, margin no 131.

23 ECtHR, Perna v. Italy, Application no. 48898/99, Judgement 5 May 2003, margin no 31; ECtHR, Iljazi v. The Former Yugoslav Republic of Macedonia, Application no. 56539/08, Judgement 3 October 2013, margin no 45.

24 ECtHR, Dusko Ivanovski v. The Former Yugoslav Republic of Macedonia, Application no. 10718/05, margin no 55.

25 ECtHR, Borisova v. Bulgaria, Application no. 56891/00, Judgement 21 December 2006, margin no 47 et seq.

26 ECtHR, Lüdi v. Switzerland, Application no. 12433/86, Judgement 15 June 1992, margin no 48.

27 ECtHR, Pichugin v. Russia, Application no. 38623/03, Judgement 23 October 2012, margin no 204.

28 In this regard see, for instance, ECtHR, Balta and Demir v. Turkey, Application no. 48628/12, Judgement 23 June 2015, margin no 55; ECtHR, Iljazi v. The Former Yugoslav Republic of Macedonia, (fn. 23), margin no 40 et seq. 
though both categories cannot strictly be separated, this division will also be followed here.

\section{Witness evidence}

\section{In general}

In contrast to documentary or other material evidence, Article 6 (3) lit. d ECHR explicitly enshrines two rights of the defendant to request evidence: 'to obtain the attendance and examination of witnesses on his behalf' and 'to examine or have examined witnesses against him'. According to the Court, the first right, with regard to calling a defence witness, mirrors the principle of equality of arms between the prosecution and the defence, as lit. $\mathrm{d}$ indicates by the words 'under the same conditions'. ${ }^{29}$ The right to examine a prosecution witness underlies the aims of a fair trial within the meaning of Article 6 (1) and (3) ECHR, namely, to enable the defendant to participate in a criminal trial effectively and to influence the outcome of criminal proceedings against him. ${ }^{30}$ In line with these aims, Article 6 (3) lit. $\mathrm{d}$ anchors 'the principle that, before an accused could be convicted, all evidence against him normally had to be produced in his presence at a public hearing with a view to adversarial argument'. In the case of prosecution evidence, the requirements of effective participation are met if the defendant gains the opportunity to examine the witness, to confront her before the trial court with his version of the case, and to have influence on the outcome of trial. ${ }^{31}$ In this regard, the rights of the defence to examine, for instance, a police informant or an undercover police officer, in accordance with Article 6 (3) lit. $\mathrm{d}$ ECHR, is restricted if, due to confidentiality reasons, their identity is concealed from the defence, ${ }^{32}$ their appearance in trial is denied, ${ }^{33}$ or they refuse to answer certain questions (for more on this see below). ${ }^{34}$ Moreover, the Court underlines that Art. 6 (1) and (3) lit. d of the Convention contains 'a presumption against the use of hearsay evidence against a defendant in criminal proceedings'. ${ }^{35}$ To entirely withhold informants and undercover officers for

29 ECtHR, Iljazi v. The Former Yugoslav Republic of Macedonia, (fn. 23), margin no 40 et seq.

30 ECtHR, Dusko Ivanovski v. The Former Yugoslav Republic of Macedonia, (fn. 24), margin no 59; see also A. Zrvandyan, Casebook on European Fair Trial Standards in Administrative Justice, 2016, p. 86; S. Bürger, Unmittelbarkeitsgrundsatz und kontradiktorische Beweisaufnahme, Zeitschrift für die gesamte Strafrechtswissenschaft (ZStW) 128(2)/2016, p. 540; Stoffers, NJW 2013, p. 1496.

31 See M. Arslan, The Right to Examination of Prosecution Witnesses, Zeitschrift für Internationale Strafrechtsdogmatik (ZIS) 6/2018, p. 219; Pauly, StV 2014, p. 456; H. Radtke, Wahrheitsermittlung im Strafverfahren. Leitprinzipien, Methoden und Grenzen, Goltdammer's Archiv für Strafrecht (GA) 2012, p. 196; Gaede, StV 2006, p. 602.

32 ECtHR, Doorson v. The Netherlands, Application no. 20524/92, Judgement 26 March 1996, margin no 72.

33 ECtHR, Scholer v. Germany, (fn. 4), margin no 56 et seq.

34 ECtHR, Pichugin v. Russia, (fn. 27), margin no 202.

35 ECtHR, Thomas v. The United Kingdom, Application no. 19354/02, Judgement 10 May 2015. 
the same reasons and to introduce their testimonies through surrogates is in conflict with this principle. ${ }^{36}$ By the highlighting of both principles, the Court does not, however, postulate strict evidence rules. It points out, at the same time, that 'Article 6 does not grant the accused an unlimited right to secure the appearance of witnesses in court', be it a defence or prosecution witness. ${ }^{37}$ Thus, the Court concludes that 'the statement of a witness does not always have to be made in court or in public if it is to be admitted as evidence'. ${ }^{38}$ A blanket assumption that 'all hearsay evidence which is crucial to a case is unreliable or incapable of proper assessment unless tested in crossexamination' would not be justifiable for the Court. ${ }^{39}$

Against this background, the exact scope of both rights of defence with regard to witness evidence can only be established by an extensive analysis of the highly complex and case-based jurisprudence of the Court on Article 6 (3) lit. d ECHR. ${ }^{40}$ In the following, only a selected part of this case law will be presented.

\section{Defence witness}

Under Article 6 (3) lit. $\mathrm{d}$ ECHR it is permissible that the national law requires the defendant to give reasons for calling a certain person as witness. Therein he may be obliged to show that the examination of that person as a defence witness is necessary in the search for the truth and will enable him to make his case before the trial court, be it with regard to the determination of guilt or the admissibility of exculpatory evidence. ${ }^{41}$ In particular, he should be able to explain what he intends 'to prove by the witness evidence proposed and how this evidence could be relevant to the outcome of the case' ${ }^{42}$ As a rule, it lies within the discretion of the domestic courts as to the

36 ECtHR, Scholer v. Germany, (fn. 4), margin no 56 et seq.; Pauly, StV 2014, p. 456; Gaede, $\mathrm{StV} 2006$, p. 602.

37 ECtHR, Krasniki v. The Czech Republic, Application no. 51277/99, Judgement 28 February 2016, margin no 75; ECtHR, Tarasov v. Ukraine, Application no. 17416/03, Judgement 31 October 2013, margin no 105.

38 ECtHR, Smajgl v. Slovenia, Application no. 29187/10, Judgement 4 October 2016, margin no 63; ECtHR, Tarasov v. Ukraine, (fn. 37), margin no 37 et seq.; see also J. van Voorhout, and E.B. Coster, Intelligence as legal evidence. Comparative criminal research into the viability of the proposed Dutch scheme of shielded intelligence witnesses in England and Wales, and legislative compliance with 6 (3) (d) ECHR, Utrecht Law Review (ULR) 2/2006, p. 138.

39 ECtHR, Al-Khawaja and Tahery v. The United Kingdom, Application no. 26766/05 22228/06, Judgement 15 December 2011, margin no 139; see also M.S. Groenhuijsen, and H. Selçuk, The Principle of Immediacy in Dutch Criminal Procedure in the Perspective of European Human Rights Law, Zeitschrift für die gesamte Strafrechtswissenschaft (ZStW) 126/2014, p. 248 et seq.; L. Bachmaier Winter, Transnational Criminal Proceedings, Witness Evidence and Confrontation: Lessons from the ECtHR's Case Law, Utrecht Law Review (ULR) 9(4)/2013, p. 127 et seq.

40 For more on this see Arslan, ZIS 6/2018, p. 218 et seq.

41 ECtHR, Tarasov v. Ukraine, (fn. 37), margin no 104; ECtHR, Dusko Ivanovski v. The Former Yugoslav Republic of Macedonia, (fn. 24), margin no 53.

42 ECtHR, Laukkanen and Manninen v. Finland, Application no. 50230/99, Judgement 3 February 2004, margin no 36. 
soundness and validity of such an evidence request, in particular under the aspect whether the witness whom the defendant seeks to adduce, is relevant for his case and the truth. ${ }^{43}$ If the defendant refrained to request before the national court to adduce witness evidence, his application before the ECtHR may be rejected on the grounds that he has not exhausted all remedies available at the national level. ${ }^{44}$ However, the Court does not exclude the existence of circumstances of specific cases under which the trial court itself might be called to hear a person as a witness, even if the defendant omits to issue a respective request. ${ }^{45}$

As a rule, the mentioned relevance is given and the defendant has a legitimate interest in requesting the hearing of a witness who will testify about the very events that later 'constituted the basis' of his conviction. Thus, an evidence request is sufficiently reasoned if it seeks to adduce persons as defence witnesses 'who had participated in or experienced the critical events at first hand'. The trial court violates the defendant's right under Article 6 (3) lit. $\mathrm{d}$ ECHR if it refuses the hearing of a direct witness by arguing that it already has their pre-trial testimonies as documentary evidence. ${ }^{46}$

In the case of Iljazi v. Former Yugoslav Republic of Macedonia, the proof of facts whether the defendant 'loaded the drugs into the truck' was, according to the Court, relevant for the defence, as it constituted the very subject matter of the accusations made against him. In the absence of any direct evidence, the trial court's refusal to admit statements of the defence witnesses 'on the ground that there was already sufficient evidence to establish the facts' deprived him of the guarantee of a fair trial within the meaning of Article $6{ }^{47}$

In the case of Borisova v. Bulgaria, the defendant stated before the trial court many times that she could refute the case of the prosecutor against her if she would be allowed to adduce persons who were also at the scene of the verbal exchange between herself and the police officer and, hence, who witnessed the events. For the Court, the fact that she could not give their names as defence witnesses was not sufficient to reject her request as it was reasonable under the circumstances of the case. In the final analysis, the trial court only heard the prosecution witnesses, rendered its judgment on the ground of a 'one-sided' taking of evidence, thereby violating the defendant's right to hear her witnesses under the same conditions as the prosecutor's witnesses. ${ }^{48}$

Due care must be taken in the application of a relevancy test in cases where the involvement of the defendant in the very same crime, in the specific case of murder, cannot be proven directly and a conviction might be primarily based 'on the assumption

43 ECtHR, Perna v. Italy, (fn. 23), margin no 29; ECtHR, Borisova v. Bulgaria, (fn. 25), margin no 46; ECtHR, Tarasov v. Ukraine, (fn. 37), margin no104; ECtHR, Iljazi v. The Former Yugoslav Republic of Macedonia, (fn. 23), margin no 40.

44 ECtHR, Het Finnancieele Dagblad B.V. v. The Niederlands, Application no. 577/11, Decision 28 June 2011, margin no 47.

45 ECtHR, Tarasov v. Ukraine, (fn. 37), margin no 104.

46 ECtHR, Dusko Ivanovski v. The Former Yugoslav Republic of Macedonia, (fn. 24), margin no 55.

47 ECtHR, Iljazi v. The Former Yugoslav Republic of Macedonia, (fn. 23), margin no 41 et seq.

$48 E C t H R$, Borisova v. Bulgaria, (fn. 25), margin no 47 et seq. 
of his being in a particular place at a particular time' and some other corroborative indirect witness statements. In such a case, the domestic courts should deal with the evidence request of the defendant with special care by which he seeks to adduce an alibi. Refusing such a request because the defence witnesses in question are his relatives, and giving no other reason with regard to a lack of relevance of their statements, also deprives the defendant of his right to a fair trial under Article 6 (1) ECHR. ${ }^{49}$

However, the right to call defence witnesses is also not absolute. The domestic courts may reject the respective evidence requests made by the defence if the interests of the proper administration of justice justify it. As far as can be seen, the Court has not yet decided on a case where the request of the defence to adduce a defence witness has been denied due to the protection of state secrets or the maintenance of confidentiality. However, as will be shown below, the issue of public interest can be raised in order to restrict the rights of the defence under Article 6 (1) ECHR. It seems that it is within the legal practice of the contracting countries, rather than the case that the defence tries to refute and rebut the testimonies of a prosecution witness, inter alia, by trying to obtain exculpatory testimonies. Besides this, the following applies if the defendant requests to adduce a defence witness: it lies within the discretion of the trial court to set the date for the hearing of the defence witness. Unless the defendant can substantiate that the conducting of the hearing on the date set by the court would impair his defence, the hearing on another date where the defendant and his lawyer are present suffices..$^{50}$ Moreover, the ECtHR makes clear that 'Article 6 (3) lit. d does not require the attendance and examination of every witness on the accused's behalf'. ${ }^{51}$ If the accusations against the defendant have already been sufficiently proven by other evidence, the trial court is allowed to demand from the defendant substantial reason for the hearing of a defence witness whose written pre-trial statements have already been introduced at the trial. ${ }^{22}$ Furthermore, a defence witness whom the defendant seeks the trial court to hear is irrelevant for his defence and his respective evidence request may be rejected if the trial court has already decided on the procedural issue, for instance, the admissibility of his police confession, in his favour, or order an alternative evidence-taking session with regard to the same question..$^{53}$ The refusal is also justified if the witness whom the defendant seeks to adduce is not 'capable of establishing' the facts underlying the accusations against him. ${ }^{54}$ The trial court is not at fault if the de-

49 ECtHR, Popov v. Russia, Application no. 26853/04, Judgement 13 July 2006, margin no 181 et seq.

50 ECtHR, Messier v. France, Application no. 25041/07, Decision 19 May 2009; ECtHR, Messier v. France, Application no. 25041/07, Judgement 30 June 2011, margin no 65 et seq.

51 ECtHR, Tarasov v. Ukraine, (fn. 37), margin no 104.

52 ECtHR, Keş v. Turkey, Application no. 17174/03, Judgement 2 December 2008, margin no 37 et seq.

53 ECtHR, Tarasov v. Ukraine, (fn. 37), margin no 105.

54 ECtHR, Perna v. Italy, (fn. 23), margin no 31. 
fence witness does not appear for the interview that the court has to schedule for another date. ${ }^{55}$

\section{Prosecution witness}

Evidence requests of the defendant, with regard to a prosecution witness, mainly concern the way in which the evidence is taken, and whether it restricts his ability to examine him. Therefore, such a question arises when the prosecution authority intends to use the testimony of a witness against the defendant, and the trial court might rely on this testimony in its verdict. ${ }^{56}$ In such a case, the right of the defence to examine a prosecution witness requires the following:

- the defendant must be informed about the identity of the witness,

- the personal appearance of the witness for examination in the trial must be afforded,

- the defendant must be enabled to follow witness testimonies acoustically and visually; and

- the defendant needs to have the opportunity to put questions to the witness and to challenge her testimonies. ${ }^{57}$

Evidence requests made by the defendant normally aim to give him these opportunities if the testimonies of the prosecution witness in question may be used against him. Upon such a request, the Court emphasises that the trial judge has to make 'every reasonable effort ... in order to ensure the attendance of the witnesses in court' and their examination by the defendant. ${ }^{58}$ In case of a non-compliance, the trial judge is obliged to account for the factual and/or legal grounds of the restrictions incurred by the defendant. ${ }^{59}$ Admittedly, the defendant can waive this right. ${ }^{60}$

55 ECtHR, Messier v. France, (fn. 50), 19 May 2009; ECtHR, Messier v. France, (fn. 50), margin no 65 et seq.

56 ECtHR, Papadakis v. The Former Yugoslav Republic of Macedonia, Application no. 50254/07, Judgement 26 February 2013, margin no 87.

57 ECtHR, Kostovski v. The Netherlands, Application no. 11454/85, Judgement 20 November 1989, margin no 42; ECtHR, Ellis, Rodrigo and Martin v. The United Kingdom, Application no. 46099/06 46699/06, Decision 10 April 2012, margin no 74; see also Arslan, ZIS 6/2018, p. 219; K. Ambos, Internationales Strafrecht, 2018, p. 488 et seq.; W. Woblers, Art. 6 Abs. 3 lit. d) EMRK als Grenze der Einführung des Wissens anonym bleibender Zeugen, in: Andreas, Donatsch et al. (eds.), Strafrecht, Strafprozessrecht und Menschenrechte Festschrift für Stefan Trechsel, 2002, p. 816.

58 ECtHR, Taal v. Estonia, Application no. 13249/02, Judgement 22 November 2015, margin no 34.

59 ECtHR, Pichugin v. Russia, (fn. 27), margin no 204; van Voorbout and Coster, ULR 2/2006, p. 139.

60 ECtHR, Doncev and Burgov v. The Former Yugolav Republick of Macedonia, Application no. 30265/09 30265/09, Judgement 12 June 2014, margin no 58 et seq. 
It is acknowledged in the jurisprudence of the ECtHR that the right to examine a prosecution witness is not absolute: the interests of society in the effective administration of criminal justice and the rights of victims may serve as legitimate grounds for restrictions on Article 6 (3) lit. d. ${ }^{61}$ In its case law, the Court recognises a number of legitimate factual and legal reasons, for instance, the vulnerability of witnesses ${ }^{62}$ the public interest in the protection of police informants, ${ }^{63}$ or the right of the witness to refuse to answer incriminating questions for reasons of self-protection. ${ }^{64}$

The Court considers that the use of informants or undercover police officers in certain areas of crime, such as terrorism, ${ }^{65}$ organised crime ${ }^{66}$ or corruption, is a necessary and effective method of investigation. ${ }^{67}$ It accepts that the national authorities, under some circumstances, are only able to conduct covert operations, and the flow of information from some criminal milieus or the future use of these persons, if they do not disclose their identity and, moreover, protect them during the criminal trial. Thus, the authorities may have a legitimate interest in concealing the identity of these persons due to confidential information or state secrets and to withhold them from the public trial hearing and defence. ${ }^{68}$

As the corresponding case law of the Court shows, in the legal practice of the contracting states, there are various methods to protect the witness in question and/or to introduce the testimonies of a prosecution witness without his examination by the defendant: steps can be taken both at the trial stage and at a previous stage of the criminal proceedings. The Court ruled on the following procedures:

- examination of the witness using location-based, acoustical or optical shielding (distortion of pictures and sounds), ${ }^{69}$

61 ECtHR, Al-Khawaja and Tabery v. The United Kingdom, (fn. 39), margin no 118.

62 ECtHR, P.S. v. Germany, Application no. 33900/96, Judgement 20 December 2001, margin no 28; ECtHR, A.G. v. Sweden, Application no. 315/09, Judgement10 January 2012; see also Nanopoulos, MLR 78(6)/2015, p. 923.

$63 E C t H R$, Lüdi v. Switzerland, (fn. 26), margin no 48.

64 ECtHR, Vidgen v. The Netherlands, Application no. 29353/06, Judgement 10 July 2012, margin no 42.

65 ECtHR, Balta and Demir v. Turkey, (fn. 28), margin no 47.

66 ECtHR, Ellis, Rodrigo and Martin v. The United Kingdom, (fn. 57), margin no 80.

67 ECtHR, Doncev and Burgov v. The Former Yugolav Republick of Macedonia, (fn. 60), margin no 52; Woblers, (f. 57), p. 813; see also the Council of Europe, Parliamentary Assembly Resolution 2038 (2015) on witness protection as an indispensable tool in the fight against organised crime and terrorism in Europe [http://assembly.coe.int/nw/xml/XRef/Xref-XML2 HTML-en.asp?fileid=21551\&lang=en].

68 ECtHR, Doncev and Burgov v. The Former Yugolav Republick of Macedonia, (fn. 60), margin no 52; ECtHR, Donohoe v. Ireland, Application no. 19165/08, Judgement 12 December 2013, margin no 81; van Voorhout and Coster, ULR 2/2006, p. 139; Renzikowski, JZ 12/1999, p. 610; see also Recommendation No. R (97) 13 of the Council of Europe Committee of Ministers to member states concerning the intimidation of witnesses and the rights of the defence [https://polis.osce.org/node/4676].

69 ECtHR, Pesukic v. Switzerland, Application no. 25088/07, Judgement 6 December 2012, margin no 42. 
- exclusion of the defendant from the court examination, ${ }^{70}$

- exclusion of the defendant and his lawyer from the court examination (in camera), ${ }^{71}$

- examination of the witness by an associate judge,,$^{72}$

- putting limitations on questions during the trial, ${ }^{73}$

- examination of the witness by an investigating judge,$^{74}$ public prosecutor ${ }^{75}$ or the police, ${ }^{76}$ and the admission of these individuals as hearsay evidence or a reading of examination records as documentary evidence, ${ }^{77}$

- acoustic and/or visual recording of a pre-stage examination of witnesses and playback of the record, ${ }^{78}$ and

- anonymising the identity of the witness. ${ }^{79}$

The use of any one of these methods does not violate per se the Convention, including in camera hearings and surrogate documentary evidence, or hearsay evidence. ${ }^{80}$ Whereas the use of in camera hearings can bring about witness testimonies that are only known by the trial court (secret evidence), ${ }^{81}$ the admission of so-called hearsay evidence enables executive authorities to control the flow of information into the criminal justice system to a considerable extent. Instead of a formal blanket judgement that such practices are not permissible under Article 6 (1) ECHR, the Court demands on a closer reflection whether and how their detrimental impact on the rights of the defence might

70 ECtHR, Ellis, Rodrigo and Martin v. The United Kingdom, (fn. 57), margin no 41; see also M. Krausbeck, Matthias, Konfrontative Zeugenbefragung. Vorgaben des Art. 6 Abs. 3 lit. d EMRK für das deutsche Strafverfahren, Tübingen 2010, p. 286.

71 ECtHR, Papadakis v. The Former Yugoslav Republic of Macedonia, (fn. 56), margin no 91; ECtHR Ivannikov v. Russia, no. 36040/07, $\$ \$ 23$ et seqq., 25 October 2016.

72 ECtHR, Balta and Demir v. Turkey, (fn. 28), margin no 45 et seq.

73 ECtHR, Pichugin v. Russia, (fn. 27), margin no 202.

74 ECtHR, Saidi v. France, Application no. 14647/89, Judgement 20 September 1993, margin no 43.

75 ECtHR, Luca v. Italy, Application no. 33354/96, Judgement 27 February 2001, margin no 40.

76 ECtHR, Birutis and others v. Lithuania, Application no. 47698/99 48115/99, Judgement 28 March 2002, margin no 15.

77 ECtHR, Delta v. France, Application no. 11444/85, Judgement 19 December 1990, margin no 37.

78 ECtHR, Schatschaschwili v. Germany, Application no. 9154/10, Judgement 15 December 2015, margin no 127 et seq.

79 ECtHR, Doncev and Burgov v. The Former Yugolav Republick of Macedonia, (fn. 60), margin no 51 et seq.; see also Recommendation Rec (2005)9 of the Council of Europe Committee of Ministers to member states on the protection of witnesses and collaborators of justice [https://www.coe.int/t/dg1/legalcooperation/economiccrime/organisedcrime/Rec\%20_2005 _9.pdf]; Recommendation No. R (97) 13 of the Council of Europe Committee of Ministers to member states concerning intimidation of witnesses and the rights of the defence [https:// polis.osce.org/node/4676].

80 See also Pauly, StV 2014, p. 456.

81 See Vogel, ZIS 1/2017, p. 28 et seq. 
be remedied. ${ }^{82}$ Moreover, even if the rights of the defence have been restricted on the grounds of a legitimate reason, the defendant must be afforded a certain balance between his interests and those of the public or witness in question. The balancing requires first of all consideration of the principle of proportionality and, secondly, the adoption of counterbalancing measures.

In terms of the principle of proportionality, a legitimate reason 'could not justify any choice of means by the authorities ...', which will put restrictions on exercising the right to examine a prosecution witness under the above-mentioned circumstances. ${ }^{83}$ The Court demands that 'any measures restricting the rights of the defence should be strictly necessary'. ${ }^{84}$ In this regard, the trial court has discretion over the question which measure will be reasonable and practicable for protecting the interests at stake, and whether it has any alternatives at its disposal..$^{85}$ The ECtHR accepts, in principle, that the choice of the trial court may not be the most advantageous or beneficial method for the defendant. ${ }^{86}$ Nevertheless, the Court limits the discretion of the trial court to the effect that the complete exclusion of the witness from the public trial 'must be a measure of last resort'. In order to take this measure, it has to give good reason that 'all available alternatives, such as witness anonymity and other special measures, would be inappropriate or impracticable'. ${ }^{87}$

With regard to the counterbalancing measures, the judicial authorities should take steps to remedy 'the handicaps under which the defence laboured sufficiently ... by the procedures followed'. ${ }^{88}$ As appropriate substitutes, the counterbalancing measures should bring about conditions, which 'as closely as ... possible' approximate 'the hearing of a witness in open court' ${ }^{89}$ Moreover, the Court regards it as a counterbalancing measure if the trial court proceeds in assessing the witness evidence with caution..$^{90}$ Furthermore, the Court draws the attention of the domestic courts to the fact that 'the more important that evidence, the more weight the counterbalancing factors would have to carry in order for the proceedings as a whole to be considered fair' ${ }^{91}$ Most importantly, the unfairness of the whole trial and the danger of a wrongful conviction, 'are all the greater if that evidence is the sole or decisive evidence against the defendant'. ${ }^{92}$ In this regard, the Court has abandoned its previous so-called sole or decisive

82 See Arslan, ZIS 6/2018, p. 221 et seq.

83 ECtHR, Birutis and others v. Lithuania, (fn. 76), margin no 30.

84 ECtHR, van Mechelen and others v. The Netherlands, Application no. 21363/93 21364/93 21427/93 22056/93, 23 April 1997, margin no 58.

85 ECtHR, Scholer v. Germany, (fn. 4), margin no 57.

86 ECtHR, Doorson v. The Netherlands, (fn. 32), margin no 54.

87 ECtHR, Al-Khawaja and Tabery v. The United Kingdom, (fn. 39), margin no 125.

88 ECtHR, Al-Khawaja and Tabery v. The United Kingdom, (fn. 39), margin no 141.

89 ECtHR, Kok v. The Netherlands, Application no. 43149/98, Decision 4 June 2000, margin no 1 Law.

90 ECtHR, Doorson v. The Netherlands, (fn. 32), margin no 76.

91 ECtHR, Batek and others v. The Czech Republic, Application no. 54146/09, Judgement 12 January 2017, margin no 40.

92 ECtHR, Al-Khawaja and Tahery v. The United Kingdom, (fn. 39), margin no 142 emphasis added. 
rule, which automatically led to a breach in the right to a fair trial whenever 'the defendant's conviction was solely or to a decisive extent based on evidence provided by an absent witness' ${ }^{93}$ It prefers rather to conduct a so-called overall fairness test, ${ }^{94}$ whereby the Court might still consider the whole trial as fair, even if the conviction of the defendant was decisively based on the testimonies of an untested witness. ${ }^{95}$ The main determinants of its jurisprudence are the reason of restriction, the importance of witness testimonies in question, and the sufficiency of counterbalancing measures for 'a fair and proper assessment of reliability of that evidence to take place'. ${ }^{96}$

\section{Documentary or other material evidence}

\section{In general}

As already mentioned above, it is compatible with Article 6 (1) that the national law formalises the request of the defendant to take evidence. In this regard, under Article 6 (1) it is permitted that the national law obliges the defendant to file a motion, giving reason therein for the relevance of the evidence in question for his defence. The national courts are vested with the power to examine the validity and soundness of these reasons. ${ }^{97}$ According to the Court, as a rule, the relevance of evidence in question is given if the latter is related to proof of his guilt, determination of sentence or a procedural issue. ${ }^{98}$

As long as the decisions of the domestic courts on the evidence request of the defence are not unreasonable or arbitrary, the Court must accept them and cannot replace them with its decision. ${ }^{99}$ Moreover, the fact that the requested evidence has been already introduced into the taking of evidence before the trial court, and used by the court against the defendant, will play a certain role. ${ }^{100}$ The prospects of a successful ev-

93 ECtHR, Schatschaschwili v. Germany, (fn. 78), margin no 112 et seq.; see also Gaede, StV 2006, p. 602; Radtke, GA 2012, p. 197; compare with A. du Bois-Pedain, Artikel 6 Abs. 3 lit. d EMRK und der nicht verfügbare Zeuge: Weist der modifizierte Lucà-Test den Weg aus der Sackgasse? Zugleich eine Besprechung von EGMR Nr. 26766/05 und 22228/06 (Große Kammer), Urteil vom 15. Dezember 2011 (Al-Khawaja und Tahery v. Großbritannien) = HRRS 2012 Nr.1, HöchstRichterliche Rechtsprechung im Strafrecht (HRRS) 3/2012, p. 121 et seq. Pauly, StV 2014, p. 457.

94 ECtHR, Schatschaschwili v. Germany, (fn. 78), margin no 118 et seq.; see also Ambos, (fn. 57), p. 490; Vogel, ZIS 1/2017, p. 28; Nanopoulos, MLR 78(6)/2015, p. 923.

$95 E C t H R$, Schatschaschwili v. Germany, (fn. 78), margin no 112 et seq.

$96 E C t H R$, Schatschaschwili v. Germany, (fn. 78), margin no 107 et seq.; doubting the capacity of the court to avoid a wrongful conviction if the prosecution evidence has not been effectively contested by the defence, Vogel, ZIS 1/2017, p. 36.

97 ECtHR, Matanovic v. Croatia, Application no. 2742/12, Judgement 4 April 2017, margin no et seq. 157.

98 ECtHR, Leas v. Estonia, (fn. 15), margin no 82.

$99 E C t H R$, Bucur und Toma v. Romania, (fn. 22), margin no 131 (unreasoned).

100 ECionHR, Cavlun v. The Netherlands, Application no. 38061/97, Decision 21 November 1998, margin no Law. 
idence request for the defence, however, diminishes whether the evidence in question can be sufficiently contested by the defence, as well as the way in which it has already been introduced. In addition, the omission of the defendant to request other alternative ways of taking evidence is detrimental to his argument that he was deprived of his evidence by the authorities. ${ }^{101}$

With regard to the request to procure a specific piece of evidence, the Court recognises some factual or legal reasons to reject respective motions of the defence and, thereby, restrict defence rights ${ }^{102}$ : for instance, irrelevance of specifically requested intelligence information for the defence of the defendant, ${ }^{103}$ or the unreachability of exculpating evidence due to its highly probable physical disappearance are sound grounds to reject the evidence request. ${ }^{104}$ The refusal is also justified if the documents which the defendant seeks to adduce are not 'capable of establishing' the facts underlying the accusations against him. ${ }^{105} \mathrm{~A}$ rather controversial reason, with which the Court has been dealing extensively, is the public interest.

\section{Secret evidence}

More specifically, the restrictions of defence rights are being justified by reference to national security, the effectivity of covert investigation methods, ${ }^{106}$ the integrity of police computer systems, ${ }^{107}$ and the methods of the intelligence services, ${ }^{108}$ in particular in the areas of organised crimes, ${ }^{109}$ drug crimes ${ }^{110}$ or terrorism. ${ }^{111}$ However, the Court emphasises that public interest cannot justify substantial restrictions on the rights of the defence. The interests of the defence must also apply in a manner appropriate to the reason of limitation. ${ }^{112}$

101 ECionHR, Jespers v. Belgium, (fn. 9), margin no 64.

102 ECtHR, Natunen v. Finland, Application no. 21022/04, Judgement 31 March 2009, margin no 40.

$103 E C t H R$, Mirea v. Romania, (fn. 22), margin no 55 et seq.

104 ECionHR, Carlotto v. Italy, Application no. 22420/93, Decision 20 May 1997.

105 ECtHR, Perna v. Italy, (fn. 23), margin no 31.

106 ECtHR, Mirilashvili v. Russia, Application no. 6293/04, Judgement 11 December 2008, margin no set seq. 202.

107 ECtHR, Dowsett v. The United Kingdom (fn. 10), margin no 18 et seq.

108 ECtHR, Botmeh and Alami v. The United Kingdom, Application no. 15187/03, Judgement 7 June 2007, margin no 42.

109 ECtHR, Rowe and Davis v. The United Kingdom, Application no. 28901/95, Judgement 16 February 2000, margin no 32.

110 ECtHR, Jasper v. The United Kingdom, Application no. 27052/95, Judgement16 February 2000, margin no 54.

111 ECtHR, Botmeh and Alami v. The United Kingdom, (fn. 108), margin no 42; see also Nanopoulos, MLR 78(6)/2015, p. 916 and 923; Q. Eijkman, Quirine and B. van Ginkel, Compatible or incompatible? Intelligence and Human Rights in Terrorist Trials, Amsterdam Law Forum (ALW) 3-4/2011, p. 5.

112 ECtHR, Chruscinski v. Poland, Application no. 22755/04, Judgement 6 November 2007, margin no 56. 
To review whether defence rights have been violated with regard to restrictions on respective evidence requests, the Court developed the following three-step test:

- whether there are legitimate and sufficient grounds for the restriction (justification) and, if so,

- how the decision-making process regarding the evidence-taking request was carried out and, finally,

- whether the result of the approach taken by the domestic court and authorities is proportionate (in particular under the consideration of whether the disadvantages incurred by the defence with regard to making his case have been compensated by adequate procedural safeguards, the relevance of the non-disclosed evidence and their use against the defendant). ${ }^{113}$

With regard to the first step, the domestic decision-making bodies, especially the trial court, meet the said obligation if they examine the question 'whether their disclosure would, at least arguably, have harmed any identifiable public interest', and give the reason that the specific restrictive measure under consideration was due to the competing interests and circumstances of the case proportionate. ${ }^{114}$

The most pivotal step of the Court's test is the second one, namely, the said decision-making process. With respect to the decision-making body, the Court examines whether it was independent and impartial, and vested with the power to decide on the matter and to review relevant evidence. For the process itself, the Court focuses on the questions of whether it was 'as far as possible' adversarial, ensured equality of arms between the prosecution and the defence, and made reasonable efforts for safeguarding the interests of the defence. ${ }^{115}$

A closer look reveals that the said decision-making process is not a simple ancillary one to the main trial regarding the determination of guilt. The decision on the seemingly mere procedural issue, whether the non-disclosure of certain evidence to the defendant due to public interest, is in many ways intertwined with the determination of guilt as the same decision-making process can even lead to the allowance of secret evidence in a criminal trial. The following summary of the case law of the Court illustrates that: If an executive authority or prosecution one-sidedly decides not to transmit or disclose that it has the evidence in question at its disposal in criminal proceedings

113 ECtHR, Matanovic v. Croatia, (fn. 97), margin no 155; ECtHR, Mirilashvili v. Russia, (fn. 106), margin no 196 et seq.; see also Nanopoulos, MLR 78(6)/2015, p. 924; Gaede, StV 2006, p. 601.

114 For the violation of this reasoning requirement see ECtHR, Mirilashvili v. Russia, (fn. 106), margin no 202 et seq.; see also ECtHR, Leas v. Estonia, (fn. 15), margin no 87 et seq.; ECtHR, Cevat Soysal v. Turkey, Application no. 17362/03, Judgement 23 September 2014, margin no 67; see also Gaede, StV 2006, p. 601.

115 ECtHR, Fitt v. The United Kingdom, Application no. 29777/96, Judgement 16 February 2000, margin no 48. 
(one-sided withholding), it thereby violates the right to a fair trial. ${ }^{116}$ However, a hailing of that breach by the appeal court is possible if the evidence in question is fully disclosed to the defence in the appeal proceedings and the appeal court is able to assess the influence of the previously non-disclosed evidence on the conviction in the light of the defendant's subsequent remarks. ${ }^{117}$ According to the Court, the defence's participation in the decision-making process by the appeal court can also be ensured if the appeal court, after gaining insight into the evidence in question in camera, provides the defence with a summary of the non-disclosed evidence. ${ }^{118}$

In addition, a judge is not a permissible decision-making body if he is, besides the procedural question of the soundness of the non-disclosure, at the same time called to clarify the question of a provocation and thus to decide on the termination of the criminal trial against the accused on the ground of evidence that he took into consideration in camera (unilateral disclosure). ${ }^{119}$ However, the appeal court can also hail that breach if, after its own inspection in camera, it finds that the judge did not draw any conclusions from the evidence in question when dismissing the termination of the trial due to an undue provocation. ${ }^{120}$ The accused's participation in the decision-making process is sufficiently ensured if the appellate assigns him a special advocate. ${ }^{121}$

A closer look into the subsequent case law of the Court reveals that a decision-making process by a judge in camera, who not only decides on the soundness of the evidence request of the defendant and on that of the non-disclosure decision, but also on procedural issues on the grounds of the non-disclosed evidence, was not found. ${ }^{122}$ For instance:

- in a jury trial, the judge decides in the above-mentioned way on providing the defendant with a jury, ${ }^{123}$ or

116 ECtHR, Rowe and Davis v. The United Kingdom, (fn. 109), margin no 65; see also Gaede, StV 2006, p. 601.

117 ECtHR, I.J.L., G.M.R. and A.K.P. v. The United Kingdom, Application no. 29522/95 and 30056/96 and 30574/96, Judgement 19 September 2000, margin no 118 et seq.; the appeal court is not a permissible decision-making body if it is not allowed to take the relevant evidence into consideration, see for example, ECtHR, Atlan v. The United Kingdom, Application no. 36533/97, Judgement 19 June 2001, margin no 30.

118 ECtHR, Botmeh and Alami v. The United Kingdom, (fn. 108), margin no 44.

119 ECtHR, Edwards and Lewis v. The United Kingdom, Application no. 39647/98 and 40461/98, Judgement 22 July 2003, margin no 58.

120 ECtHR, O'Farrell and others v. The United Kingdom, Application no. 31777/05, Judgement 5 February 2013, margin 54 et seq.

121 ECtHR, Austin v. The United Kingdom, Application no. 39692/09, 40713/09, 41008/09, 39692/09 40713/09, 41008/09, Judgement 10 January 2017, margin no 59; for more information on the practice in the United Kingdom, see Nanopoulos, MLR 78(6)/2015, p. 916.

122 Compare with Gaede, StV 2006, p. 601.

123 ECtHR, Twomey, Cameron and Gutbrie v. The United Kingdom, Application 67318/09, 22226/12, Decision 8 May 2013, margin no 38. 
- in a court trial, the judge decides on the lawfulness of the collection of evidence ${ }^{124}$ or on the lawfulness of the refusal of access to the file. ${ }^{125}$

The Court even allows a decision-making process by the judge in camera who may gain unilateral knowledge from the non-disclosed evidence with regard to the determination of guilt, as long as this judge, inter alia, explicitly excludes such a use of evidence in question. ${ }^{126}$

According to the Court, the judge of a jury or of another court, who will neither decide on a related procedural issue nor on the guilty party, in their responsibility afford all guarantees of the decision-making body and process, when they decide on the disclosure issue in camera, observe procedural safeguards ensuring adequate participation of the defence and take into account all concerned interests. In that case, the decision-making bodies may even come to a conclusion that the non-disclosure of exonerating evidence is justified when the public interest is at stake. ${ }^{127}$ The judge of the jury trial, as the decision-making body in an in-camera hearing, may even not fully disclose the reasons for his decision in finding the non-disclosure of the prosecution justified. ${ }^{128}$ According to the Court, it is, in principle, compatible with the protection of the defendant's rights of defence under Article 6 (1) of the ECHR if the national law, in balancing public interest with defence interests in favour of the former, attaches more importance to the fact that the evidence in question is rather incriminating for the defence. ${ }^{129}$ Finally, the judge may confirm the soundness of the non-disclosure and reject the respective evidence request of the defence if he finds that the evidence in question is irrelevant for the defence in view of the case that the latter intends to make for the determination of guilt. ${ }^{130}$ For the Court, under Article 6 (1) of the ECHR it is permissible that the defendant might feel forced in the decision-making process to waive this right to remain silent in order to convince the judge of the relevance of the non-disclosed evidence for his case. ${ }^{131}$

Finally, a closer look into the case law of the Court reveals that the contracting state pursues policies protecting confidential or sensitive material or state secrets as evidence

124 ECtHR, Mirilashvili v. Russia, (fn. 106), magin no 204 et seq.

125 ECtHR, Berardi and others v. San Marino, Application no. 24705/16 24818/16 33893/16, Decision 2 May 2017, margin no 68 et seq.

126 ECtHR, Donohoe v. Ireland, (fn. 68), margin no 88; critical of this jurisprudence, Vogel, ZIS 1/2017, p. 29 and 35.

127 ECtHR, Jasper v. The United Kingdom, (fn. 110), margin no 51 et seq.; see in this regard Resolution 1838 (2011), Abuse of state secrecy and national security: obstacles to parliamentary and judicial scrutiny of human rights violations [http://assembly.coe.int/nw/xml/ XRef/Xref-XML2HTML-EN.asp?fileid=18033\&lang=en].

128 ECtHR, Fitt v. The United Kingdom, (fn. 115), margin no 48.

129 ECtHR, Mckeown v. The United Kingdom, Application no. 6684/05, Judgement 11 January 2011, margin no 47 et seq.; ECtHR, Edwards and Lewis v. The United Kingdom, (fn. $119)$, margin no 58.

130 ECtHR, Fitt v. The United Kingdom, (fn. 115), margin no 47.

131 ECtHR, Rajcoomar v. The United Kingdom, Application no. 59457/00, Decision 14 December 2004. 
in criminal proceedings, not only by methods of one-sided withholding, but also by those of unilateral or restricted disclosure. To these primary protection methods, secondary measures might be added, ones which mainly flank the primary protection modes: notably, the exclusion of the public, refusal of access to court files and the nondisclosure of the grounds for judgment. As these restrictions may also affect the general transparency of the criminal trial, they will be discussed in more detail under a separate heading.

\section{Transparency}

\section{Restrictions on case files}

It may be sufficient for the protection of confidential information to restrict access to case files, while at the same time allowing the defence to ascertain the contents of the evidence. This may be in the case of evidence that has been collected by using covert investigative methods and which, at the same time, contains information about the method itself (such as the covert seizure of drugs by post and related protocols). ${ }^{132}$ According to the Court, the protection of covert police investigative methods is a legitimate and sufficient reason to restrict the access of the defence to case files, with the effect that the defence is only allowed to inspect the files at the court registry under the further limitation of not being allowed to take notes of evidence classified as confidential.

In the case of Welke and Bialek v. Poland, the Court pointed out that access, as such, had not been denied and that the defence was aware of all the evidence, even if only in the form of being memorised. Moreover, the further restriction imposed on the defence, namely, to respect confidentiality during giving evidence before the trial court in the judicial proceedings, was not per se incompatible with Article 6 (1) ECHR if no disadvantage had been incurred by the defence. The Court pointed out that in the concrete case, the defence had raised no objection in this regard, as can be seen from the lack of any corresponding defence. Finally, the Court referred to the fact that the prosecutor had also been subject to the same restrictions. ${ }^{133}$

The ECtHR came to a different conclusion in a number of other cases involving the so-called lustration process in Poland. The Court considers these proceedings criminal in the sense of Article 6 (1) of the ECHR. ${ }^{134}$ In the case of Gorny, the defence could only inspect the case files at the court's registry. The notes made during this inspection also had to be entered in a booklet that had to be left at the registry. Therefore, the defence could only memorise the file's contents, refer to it during the taking of evi-

132 ECtHR, Welke and Bialek v. Poland, Application no. 15924/05, Judgment 1 March 2011, margin no 20 et seq.; see also ECtHR, Leas v. Estonia, (fn. 15), margin no 82 et seq.

133 ECtHR, Welke and Bialek v. Poland, (fn. 132), margin no 63.

134 ECtHR, Gorny v. Poland, Application no. 50399/07, Judgement 8 June 2010, margin no 31. 
dence before the trial court, and call an expert witness solely on the basis of memory. ${ }^{135}$ Not only this broad range of limitations on the inspection of case files, but in addition the following circumstances of the decision-making process, with regard to the confidentiality issue, led to a violation of Article 6 (1) and (3) ECHR: unlike the above-mentioned case of Welke and Bialek, neither the Polish State Security Bureau nor the national courts could give specific reasons which would have convinced the ECtHR of the existence of legitimate public interest in the confidentiality of the documents in question. On the other hand, the Court expressed its concerns as to whether intelligence files from the Communist era could ever justify such interests. Second, the State Security Bureau itself was empowered to classify documents in question as confidential, even though they were used as incriminating material in the lustration process against the defendant. The lack of independency under which this decision-making process suffered could not be removed by the trial court, which ruled again on the restriction of the file access right of the defence. Third, unlike the limited access of the defence, the prosecution's representative had full access to the files. As a result of the overall effect of these shortcomings, the defendant had a heavy burden of counterproof, and his ability to refute inculpatory material against him was severely impaired. Fourth, and finally, the confidential documents in question accounted for a considerable part of the incriminating evidence against him. ${ }^{136}$

\section{Restrictions on the publicity of the court hearing}

Another measure of secondary protection of confidential information as evidence in criminal proceedings is the exclusion of the public. Moreover, in this case the defence has no evidence withheld. ${ }^{137}$ This measure aims, for instance in the case of witness evidence, to avoid an unveiling of the witness's identity by the public and to prevent any public influence on the witness. ${ }^{138}$ Nevertheless, the exclusion of the public throughout the trial hearing not only affects the transparency of the criminal trial in general, but also affects the defendant's right to a public trial, which is explicitly anchored in Article 6 (1). According to the ECtHR, the publicity of the court hearing protects the defendants against a secret administration of justice without public scrutiny. At the same time, it is one of the means by which confidence in the court system can be maintained in democratic societies. The publicity contributes to achieving the objective of

135 ECtHR, Gorny v. Poland, (fn. 134), margin no 37; see also ECtHR, Bobek v. Poland, Application no. 68761/01, Judgement 17 July 2007, margin 59 et seq.; ECtHR, Luboc v. Poland, Application no. 28481/03, Judgement 15 January 2008, margin no 59 et seq.

136 ECtHR, Gorny v. Poland, (fn. 134), margin no 33 et seq.

137 ECtHR, Welke and Bialek v. Poland, (fn. 132), margin no 77 et seq.; ECtHR, Volkov v. Russia, Application no. 64056/00, Judgement 4 December 2007, margin no 26 et seq.

138 ECtHR, Welke and Bialek v. Poland, (fn. 132), margin no 75 et seq.; see also, in this regard, Recommendation of the Council of Europe No. R (97) 13 Concerning Intimidation of Witnesses and the Rights of the Defence, III. Measures to be taken in relation to organised crime. 
Article 6 (1) of the ECtHR, namely, the fair conduct of the trial hearing, and to making the administration of justice transparent. ${ }^{139}$

Despite its importance, the defendant's right to have a public hearing is also not absolute. Article 6 (1) explicitly allows restrictions as follows: '.. public may be excluded from all or part of the trial in the interests of morals, public order or national security in a democratic society, where the interests of juveniles or the protection of the private life of the parties so require, or to the extent strictly necessary in the opinion of the court in special circumstances where publicity would prejudice the interests of justice'. In particular, in criminal proceedings in which the results of covert investigations are the subject of the taking of evidence by the court, the exclusion of the public is an often-taken measure. To justify the exclusion, references are made to the fact that the evidence of the covert measures in their entirety can be discussed only by including circumstances which still require confidentiality towards the general public. The same applies to the hearing of the police officers involved in these measures as witnesses, whose identity must be kept confidential. The relevant reason for excluding the public in such cases is the protection of the interests of the administration of justice under Article 6 (1) of the ECHR. ${ }^{140}$ According to the Court, the exclusion of the public is justified if it is necessary for the protection of witnesses, and the promotion of the unimpeded taking of evidence and communication between the parties of the trial in order to establish the truth. ${ }^{141}$

In the case of Vernes v. France, the defendant, the chairman of a financial company, claimed that his right to a public hearing had been violated as the former French Security and Exchange Commission (COB) had not held the sanctioning process publicly, as the rule of proceedings did not require this. For the Court, 'the technical nature of proceedings in question', by which the defendant was sanctioned with a permanent prohibition from exercising certain economic activities, was not sufficient reason to justify an exception to the requirements of transparency and the right of the defendant. ${ }^{142}$

The Court accepts that the administration of justice may require the exclusion of the public in criminal trials against serious crimes, for example, organised drug-related crime, in order to achieve the conviction of the perpetrators with the help of evidence which cannot be taken in case of the publicity of the hearing. ${ }^{143}$ However, the very gravity of the offence of which the accused is charged, for instance, the perpetration of a terrorist attack, cannot justify restricting one of the fundamental elements of the

139 ECtHR, Bobek v. Poland, (fn. 135), margin no 66; see also Zrvandyan, (fn. 30), p. 74.

140 ECtHR, Welke and Bialek v. Poland, (fn. 132), margin no 75 et seq.; R. Esser, in: LöweRosenberg, Die Strafprozessordnung und das Gerichtsverfassungsgesetz. Vol. 10 (EMRK/ IPBPR), 26th ed, 2012, Artikel 6 EMRK, margin no 443.

141 ECtHR, Nevskaya v. Russia, Application no. 24273/04, Judgement 11 October 2011, margin no 36.

142 ECtHR, Vernes v. France, Application no. 30183/06, Judgement 20 January 2011, margin no 32 .

143 ECtHR, Welke and Bialek v. Poland, (fn. 132), margin no 77 et seq. 
right to a fair trial under Article 6 (1) ECHR, such as the publicity of the hearing. The ECHR draws the attention of the domestic courts to the fact that the legal qualification of the offence, at the earlier stage of the taking of evidence, can still be primarily traced back to the prosecutor's decision. Thus, it is necessary for the trial court to exercise due caution and not to base its decision too hastily, with regard to the exclusion of the public, on the said assessment of the prosecutor who has not yet reviewed the issue. Otherwise, the court's independence from the prosecution, as well as from the executive, will suffer. ${ }^{144}$ Moreover, a decision of the court to exclude the public from a hearing must be sufficiently reasoned. The reasoning is lacking if the trial court made the assessment that in the case of a public hearing the accused will endanger other participants of the trial or evidence only by referring to the seriousness of the allegations and the gravity of expected penalties. The trial court must specify how loss of evidence can occur due to the publicity of the hearing. Its corresponding evaluations must be supplemented by balancing conflicting interests. A failure to state reasons in this regard constitutes a violation of Article 6 (1) of the ECHR. ${ }^{145} \mathrm{~A}$ reasoning is also not to be given referring merely to 'the protection of the victim, the witnesses, the other parties and the nature of the allegations'. ${ }^{146}$

The Court requires also, with regard to the decision on the exclusion of the public from the hearing, that the respective decision-making process of the trial court observes the basic principles of a fair trial. For example, if the trial court receives information from the police to the effect that the accused is the leader of a criminal organisation and therefore it is expected that he will put pressure on witnesses, this evidence in itself, with regard to a procedural issue, must be first documented. In a second step, the court should give the other concerned persons the opportunity to participate in the decision-making process. To this end, the court must inform the defence of the said evidence and grant it an opportunity to comment. Moreover, it must take possible motions of the prosecution witness into question, and the prosecution and observations of the defence into account. After taking all these steps, the trial court can be expected to make a reasonable decision on the procedural issue on whether the exclusion of the public in the interests of the administration of justice is justified, or not. ${ }^{147}$

Finally, even if the exclusion of the public is justified, its reach must be necessary only in each specific case. Thus, the exclusion of the public for the whole trial is not necessary if, for example, the evidence in question will be taken within one single session. ${ }^{148}$

144 ECtHR, Belashev v. Russia, Application no. 28617/03, Judgement 4 December 2008, margin no 86.

145 ECtHR, Nevskaya v. Russia, (fn. 141), margin no 40 et seq.

146 ECtHR, Belashev v. Russia, (fn. 144), margin no 85.

147 ECtHR, Volkov v. Russia, (fn. 137), margin no 30 et seq.

148 ECtHR, Pichugin v. Russia, (fn. 27), margin no 187. 
3. Restrictions on the publicity and disclosure of court judgments

The third measure of secondary protection of confidential information in criminal proceedings as evidence is the non-disclosure of the grounds for the judgment of the criminal court.

Whereas Article 6 (1) guarantees the holding of a public hearing and a public pronouncement of the judgment, it does not entail any requirement about the access of the public and of the defendant to the reasoning behind a delivered judgement. The ECHR considers both guarantees implicitly enshrined in the general principle of publicity of the trial hearing under Article 6 (1) ECHR. ${ }^{149}$ What is meant, however, is not a strictly and isolated understanding of publicity of the grounds of judgment. The Court is flexible and, in view of the various ways of their disclosure in different countries, is willing to accept divergent kinds of public disclosure, as long as the purpose of Article 6 (1) ECHR, namely, the accessibility of judgments to the public, is achieved. ${ }^{150}$ Depending on the nature of the proceedings, the requirement of disclosure may be satisfied if a copy of the grounds for the judgment can be obtained from the registry at the court or sent when a request is made, or if the grounds of the judgment are published in an official collection of case law of the court. ${ }^{151}$

The right to the publicity and disclosure of the court judgements is also not absolute. If the trial court has already excluded the public from the hearing in a justified way in order to protect covert police investigation methods, it will not infringe Article 6 (1) ECHR if only the operative part of the judgement is pronounced in the public hearing, ${ }^{152}$ but the grounds of the judgment is disclosed to the accused in a closed session. ${ }^{153}$ In the case of Hadjianastassiou, however, the ECtHR found a violation of Article 6 ECHR because the defendant did not receive a copy of the grounds for the judgement, arguably, as they also contained information regarding a national weapon system. The Court pointed out that the defendant, due to the non-disclosed judgment, could invoke only limited legal errors when filing the appeal against the judgment. ${ }^{154}$

In two other Polish cases relating to the so-called lustration proceedings, the ECtHR also found that Article 6 ECHR had been infringed because of the non-disclosure of the grounds of the judgment. In both cases, the courts publicly pronounced the operative part of the judgment, but the reasoning behind the decision was only available at the office for inspection by the defendants because it allegedly contained confiden-

149 ECtHR, Bobek v. Poland, (fn. 135), margin no 66 et seq.; see also Zrvandyan, (fn. 30), p. 115.

150 ECtHR, Welke and Bialek v. Poland, (fn. 132), margin no 83 et seq.

$151 E C t H R$, Bobek v. Poland, (fn. 135), margin no 66 et seq.

152 Consisting of the identity of the accused, the allegations made against him, their legal qualification, the court's determination on guilt, and sentence and costs.

$153 E C t H R$, Welke and Bialek v. Poland, (fn. 132), margin no 84 et seq; see also ECtHR, Kennedy v. The United Kingdom, Application no. 26839/05, Judgement 18 May 2010, margin no 188 et seq.; Zrvandyan, (fn. 30), p. 116.

154 ECtHR, Hadjianastassiou v. Greece, Application no. 12945/87, Judgement 16 December 1992, margin no 34 et seq. 
tial information. ${ }^{155}$ In the case of Bobek, the publicly pronounced part of the verdict consisted of a brief statement that the defendant had made a false declaration. It entailed neither the factual findings nor the assessment of evidence nor the legal elaborations on the accusations raised against him. According to the ECtHR, the scope of that disclosure to the public was insufficient in order for it to effectively assess the decision-making practice of the domestic judicial system and the transparency of the proceedings. ${ }^{156}$

\section{Summary}

The right to a fair trial guarantees the defendant the right to request for the adducing and procuring of exculpatory witnesses, and documentary and other material evidence in criminal trial. At the same time, the ECtHR recognises the non-absolute nature of the right of the defence to examine the witnesses and of the duty of the prosecution to disclose evidence at its disposal. In particular, state authorities are allowed recourse to a broad set of primary and secondary protection measures in order to preserve public interest in criminal proceedings, including the confidentiality of covert investigation methods and witness identities as sensitive information or state secrets. As long as the national courts observe, with due diligence, the procedural requirements, in particular giving a good reason for the justification of restrictions in writing, trying to reach a balance between conflicting interests and paying attention to the diminished values of hearsay evidence, the ECtHR does neither object to their choice of methods nor to the material conclusion that some evidence, even exculpatory, must be withheld entirely from the defence in a criminal trial. The most peculiar consequence of this ruling is that the trial courts might, under some circumstances, have knowledge of witness testimonies, documents or other material evidence that is unknown to the defendant in a criminal trial. In the final analysis, the ECtHR places a considerable amount of trust into the hands of the national courts, as regards the capacity to avoid a wrongful judgement and to observe the fairness of the trial, and, consequently, the rights of the defence are suffering.

155 ECtHR, Bobek v. Poland, (fn. 135), margin no 64; ECtHR, Luboc v. Poland, (fn. 135), margin no 66.

156 ECtHR, Bobek v. Poland, (fn. 135), margin no 67. 